\title{
UJI EFEK EKSTRAK UMBI BAWANG PUTIH (Allium sativum L.) TERHADAP KADAR GLUKOSA DARAH TIKUS WISTAR (Rattus norvegicus) YANG DIINDUKSI ALOKSAN
}

\author{
${ }^{1}$ Bimbi Putri Cahya, \\ ${ }^{2}$ Christi Mambo \\ ${ }^{2}$ Mona P. Wowor \\ ${ }^{1}$ Kandidat Skripsi Fakultas Kedokteran Universitas Sam Ratulangi Manado \\ ${ }^{2}$ Bagian Farmakologi dan Terapi Fakultas Kedokteran Universitas Sam Ratulangi \\ Email: cahyaputribimbi@yahoo.com
}

\begin{abstract}
Garlic (A. sativumL.) is one of many herbal medicine that have been used worldwide to prevent and treat a lot of disease, for example to treat diabetes mellitus. This research aimed to evaluate the effect of garlic bulbs extract administration on elevated blood glucose levels on Wistar rats ( $R$. norvegicus) induced by alloxan. The subjects inthis research were male Wistar rats with total of 18 samples divided into six groups as follows negative control group and five hyperglycemic groups induced by $130 \mathrm{mg} / \mathrm{kgBW}$ of alloxan. Garlic bulbs extract was administered with dose of $3 \mathrm{mg} / 200 \mathrm{gBW}$ of rat, $6 \mathrm{mg} / 200 \mathrm{gBW}$ of rats, and $12 \mathrm{mg} / 200 \mathrm{gBW}$ on each groups of hyperglycemic rats, insulin analogue was administered on positive control groups of hyperglycemic rats, and only alloxan was given to the last group. Blood glucose levels was measured on day zero, day one and day two every six hours on 0,6 , 12,18 , and 24. Data from the measurement showed that $6 \mathrm{mg} / 200 \mathrm{gBW}$ and $12 \mathrm{mg} / 200 \mathrm{gBW}$ of garlic bulbs extract can reduce elevated blood glucose levels on Wistar rats. Garlic bulbs extract has shown effect on reducing elevated blood glucose levels on Wistar rats induced by alloxan.
\end{abstract}

Keywords: Allium sativum L., Garlic Bulbs, Blood Glucose Levels, Alloxan

\begin{abstract}
Abstrak: Bawang putih (A. Sativum L.) diyakini masyarakat sebagai salah satu tanaman obat yang mampu mencegah dan mengobati berbagai penyakit, salah satunya diabetes. Penelitian ini bertujuan untuk menguji apakah pemberian ekstrak umbi bawang putih dapat menurunkan kadar glukosa darah tikus Wistar ( $R$. norvegicus) yang diinduksi aloksan. Subjek penelitian berupa tikus Wistar jantan berjumlah 18 ekor yang dibagi dalam 6 kelompok, terdiri atas satu kelompok kontrol negatif dan lima kelompok tikus Wistar yang diberi aloksan dengan dosis $130 \mathrm{mg} / \mathrm{kgBB}$ yang menyebabkan tikus Wistar dalam keadaan hiperglikemik. Tikus hiperglikemik diberi ekstrak umbi bawang putih dengan dosis $3 \mathrm{mg} / 200 \mathrm{gBB}$ tikus, $6 \mathrm{mg} / 200$ gBB tikus, dan 12 mg/200 gBB tikus, kelompok kontrol positif diberi analog insulin, dan satu kelompok hanya diberi aloksan. Data diperoleh dari pemeriksaan kadar glukosa darah pada semua kelompok tikus Wistar pada hari ke nol, pertama, dan kedua pada jam ke-0, 6, 12, 18, dan 24. Hasil penelitian menunjukkan bahwa pemberian ekstrak umbi bawang putih dengan dosis $6 \mathrm{mg} / 200 \mathrm{gBB}$ tikus dan $12 \mathrm{mg} / 200$ gBB tikus mempunyai efek menurunkan kadar glukosa darah tikus Wistar.
\end{abstract}

Kata kunci: Allium sativum L., Umbi Bawang Putih, Kadar Glukosa Darah, Aloksan

Diabetes melitus (DM) merupakan penyakit kronik yang masih menjadi masalah kesehatan utama di Indonesia. DM adalah penyakit metabolik dengan karakteristik 
hiperglikemia kronik akibat terganggunya metabolisme karbohidrat, lemak, dan protein yang terjadi karena kelainan sekresi insulin, kerja insulin, atau keduanya. ${ }^{1}$

Menurut data International Diabetes Federation (IDF) tahun 2013 Indonesia menempati peringkat ke-7 sedunia dengan jumlah penderita diabetes sebanyak 8,5 juta orang. ${ }^{2}$ Hasil Riset Kesehatan Dasar (Riskesdas) tahun 2013 menunjukkan prevalensi penderita DM yang terdiagnosis dokter di Indonesia yakni 1,5\%, dengan prevalensi tertinggi terdapat di DI Yogyakarta (2,6\%), DKI Jakarta (2,5\%), Sulawesi Utara (2,4\%) dan Kalimantan Timur (2,3\%). ${ }^{3}$

The World Health Organization Expert Committe on Diabetes telah merekomendasikan bahwa ramuan obat tradisional dapat diteliti lebih lanjut untuk pengobatan diabetes. ${ }^{4}$ Umbi bawang putih dipercaya dapat menurunkan kadar glukosa darah pada penderita diabetes. Di Asia, Eropa, dan Timur Tengah, bawang putih dikonsumsi sebagai obat tradisional untuk penderita diabetes.

\section{METODE PENELITIAN}

Penelitian ini menggunakan metode eksperimental. Penelitian ini dilakukan sejak bulan September 2014 - Januari 2015 di Laboratorium Farmakologi dan Terapi Fakultas Kedokteran Universitas Sam Ratulangi. Subjek penelitian terdiri dari 18 ekor tikus Wistar jantan.

\section{Alat dan Bahan Penelitian}

Alat yang digunakan dalam penelitian ini terdiri dari wadah plastik, kawat kasa, botol minuman, wadah makanan, oven, blender, corong pemisah, kertas saring, cawan petri, labu erlenmeyer, timbangan analitik, batang pengaduk, gelas ukur, glukometer, gunting, kapas, stopwatch, sonde lambung, dan semprit 1 cc. Bahan yang digunakan terdiri dari bawang putih, etanol 70\%, aloksan, analog insulin, aquades, dan pakan AD2.

\section{Hewan Uji}

Hewan uji dibagi dalam enam kelompok. Sebelum pengukuran pada hari ke nol (H0), semua tikus dipuasakan selama 12 jam. Setelah 12 jam kadar glukosa darah puasa semua tikus diperiksa, setelah itu satu kelompok tikus hanya diberikan aquades sedangkan lima kelompok tikus diberikan aloksan dengan dosis $130 \mathrm{mg} / \mathrm{kgBB}$ tikus untuk menginduksi kerusakan sel B pankreas sehingga glukosa darah tikus meningkat. Kadar glukosa darah semua tikus diperiksa kembali pada hari pertama (H1) setelah 24 jam pemberian aloksan dan pada awal hari kedua (H2) jam ke-0. Setelah kadar glukosa darah diukur, semua kelompok tikus diberikan perlakuan. Kelompok kontrol positif diberikan analog insulin dengan dosis $0,7 \mathrm{U} / \mathrm{kgBB}$ tikus, dan tiga kelompok diberikan ekstrak umbi bawang putih dengan dosis $3 \mathrm{mg} / 200 \mathrm{gBB}$ tikus, $6 \mathrm{mg} / 200 \mathrm{gBB}$ tikus, dan $12 \mathrm{mg} / 200$ gBB tikus. Kadar glukosa darah pada semua tikus kemudian diperiksa pada jam ke-6, 12, 18, dan 24. Semua sampel darah diambil dari pemotongan ujung ekor tikus dan kadar glukosa darah diukur dengan glukometer.

\section{Penentuan Dosis dan Pemberian Aloksan}

Penelitian ini menggunakan aloksan dengan dosis $130 \mathrm{mg} / \mathrm{kgBB}^{7} \quad$ Aloksan diberikan secara intraperitoneal pada perut tikus bagian bawah.

\section{Penentuan Dosis dan Pemberian Analog Insulin}

Berat badan rata-rata manusia dewasa di Indonesia adalah $50 \mathrm{~kg}$. Dosis yang digunakan untuk manusia dewasa yang memiliki kadar glukosa darah $>180 \mathrm{mg} / \mathrm{dL}$ adalah 6 U novomix. ${ }^{8}$ Perhitungan pemberian dosis berdasarkan pada rumus Human Equivalent Dose (HED) based on Body Surface Area (BSA). ${ }^{9}$ 
$\operatorname{HED}(\mathrm{U} / \mathrm{kg})=6 \mathrm{U} / 50 \mathrm{~kg}=0,12 \mathrm{U} / \mathrm{kg}$

HED $(\mathrm{U} / \mathrm{kg})=$ animal dose $(\mathrm{mg} / \mathrm{kg}) \times \frac{\text { animal } \mathrm{Km}}{\text { human } \mathrm{Km}}$

Animal dose $(\mathrm{U} / \mathrm{kg})=0,12 \mathrm{U} \times \frac{37}{6}$

Animal dose $(\mathrm{U} / \mathrm{kg})=0,74 \mathrm{U} / \mathrm{kg}$ BB dibulatkan menjadi 0,7 U/kg BB

Analog insulin diberikan secara subkutan pada bagian punggung tikus Wistar.

\section{Ekstrak Umbi Bawang Putih}

Umbi bawang putih yang sudah dikeringkan di oven dihaluskan dengan menggunakan blender. Sebanyak 424,31 gram tepung umbi bawang putih diekstraksi dengan cara maserasi menggunakan $2000 \mathrm{ml}$ etanol $70 \%$. Setelah dimaserasi selama 10 hari (setiap hari diaduk), hasil larutan disaring menggunakan kertas saring, didapatkan filtrat sebanyak $1300 \mathrm{ml}$. Filtrat kemudian ditempatkan dalam cawan petri dan diuapkan sampai didapatkan ekstrak pekat sebanyak 134,39 gram. Ekstrak inilah yang digunakan dalam penelitian.

\section{Penentuan Dosis dan Pemberian Ekstrak}

Dosis ekstrak umbi bawang putih yang digunakan untuk manusia dewasa dengan berat badan $50 \mathrm{~kg}$ yaitu 7,2 gram/hari. ${ }^{10}$ Faktor konversi dari manusia $70 \mathrm{~kg}$ ke tikus 200 g yaitu 0,018. ${ }^{11}$

Dosis pada manusia $=\frac{\text { Berat ekstrak pekat umbi bawang putih }}{\text { Berat umbi bawang putih }} \times 7,2$ gram/hari

Dosis pada manusia $=\frac{134 \text { gram }}{2000 \text { gram }} \times 7,2$ gram $/$ hari $=483,8 \mathrm{mg} / \mathrm{hari}$

Dosis ekstrak pada tikus $=\frac{50}{70} \times 0,018 \times 483,8=6,22 \mathrm{mg} / 200 \mathrm{~g}$ tikus/hari

Dibuat sediaan ekstrak sebanyak 1000mg di larutkan dalam $100 \mathrm{ml}$ aquades.

Volume pemberian pada tikus $=6,22 \mathrm{mg} / 1000 \mathrm{mg} \times 100 \mathrm{ml}=0,6 \mathrm{ml}$

Dosis ekstrak yang digunakan yaitu 3 $\mathrm{mg} / 200$ gBB tikus dengan volume pemberian $0,3 \mathrm{ml}, 6 \mathrm{mg} / 200 \mathrm{gBB}$ tikus dengan volume pemberian $0,6 \mathrm{ml}$, dan 12 $\mathrm{mg} / 200 \mathrm{gBB}$ tikus dengan volume pemberian 1,2 ml. Ekstrak diberikan secara oral dengan menggunakan sonde lambung dan semprit.

\section{HASIL PENELITIAN}

Pengukuran kadar glukosa darah dilakukan sebanyak 7 kali yaitu hari ke nol (H0), hari pertama (H1), hari kedua (H2) jam ke-0 sebelum perlakuan dan jam ke-6, 12, 18, dan 24 setelah perlakuan. Kelompok satu (K1) merupakan kelompok kontrol negatif yaitu kelompok yang hanya diberikan aquades, kelompok dua (K2) merupakan kelompok kontrol positif yaitu kelompok yang diberikan aloksan dan analog insulin, kelompok tiga (K3) merupakan kelompok yang hanya diberikan aloksan, kelompok empat (K4), lima (K5), dan enam (K6) merupakan kelompok perlakuan yang diberikan dosis ekstrak umbi bawang putih yang berbeda yaitu 3 mg/200 gBB, 6 mg/200 gBB, dan $12 \mathrm{mg} / 200 \mathrm{gBB}$. Hasil pengukuran seluruh kelompok dapat dilihat pada Tabel 1.

\section{BAHASAN}

Hasil pengukuran kadar glukosa darah pada kelompok satu yaitu kelompok kontrol negatif yang hanya diberikan aquades, dari hari ke nol hingga hari kedua jam ke-24 menunjukkan kadar glukosa darah masih dalam batas normal yaitu 50$135 \mathrm{mg} / \mathrm{dl}^{12}$ Glukosa darah pada ketiga tikus masih dalam batas normal karena tidak diberikan agen diabetogenik maupun agen hipoglikemik.

Kadar glukosa darah hewan uji pada kelompok dua yaitu kelompok kontrol positif mengalami penurunan pada hari 
kedua jam ke-6, 12, dan 18 setelah pemberian analog insulin karena analog insulin berikatan dengan reseptor insulin sehingga meningkatkan ambilan glukosa darah, selain itu analog insulin juga menghambat pengeluaran glukosa oleh hepar. Kadar glukosa darah mengalami peningkatan pada hari kedua jam ke-24 karena durasi kerja dari analog insulin telah habis. Analog insulin yang digunakan yaitu Novomix memiliki durasi kerja kurang dari 24 jam. ${ }^{13}$

Pada kelompok tiga yaitu kelompok yang diberikan aloksan, kadar glukosa darah pada ketiga hewan uji terus meningkat hingga hari kedua jam ke-24. Kenaikan kadar glukosa darah ini dipengaruhi oleh aktifitas dari aloksan yang menyebabkan terbentuknya oksigen reaktif yang pada proses selanjutnya akan merusak DNA pulau Langerhans pankreas yang mengakibatkan sel $\beta$ pankreas menjadi nekrosis, selain itu terjadi gangguan pada sensitivitas insulin perifer. Hal ini mengakibatkan kadar glukosa darah pada hewan uji meningkat. $^{7}$

Tabel 1. Kadar glukosa darah seluruh kelompok

\begin{tabular}{|c|c|c|c|c|c|c|c|c|}
\hline \multirow{2}{*}{ Kelompok } & \multirow{2}{*}{ Hewan Uji } & \multirow{2}{*}{$\begin{array}{c}\mathrm{H} 0 \\
(\mathrm{mg} / \mathrm{dl})\end{array}$} & \multirow{2}{*}{$\begin{array}{c}\mathrm{H} 1 \\
\text { (mg/dl) }\end{array}$} & \multicolumn{5}{|c|}{$\begin{array}{c}\mathrm{H} 2 \\
(\mathrm{mg} / \mathrm{dl})\end{array}$} \\
\hline & & & & 0 & 6 & 12 & 18 & 24 \\
\hline \multirow{4}{*}{ K1 } & Tikus A1 & 119 & 121 & 69 & 59 & 103 & 78 & 86 \\
\hline & Tikus A2 & 102 & 89 & 124 & 106 & 125 & 120 & 90 \\
\hline & Tikus A3 & 80 & 116 & 107 & 67 & 94 & 90 & 90 \\
\hline & Rata-rata & 100,3 & 108,7 & 100 & 77,3 & 107,3 & 96 & 88,7 \\
\hline \multirow{4}{*}{ K2 } & Tikus B1 & 81 & 190 & 476 & 450 & 371 & 87 & 600 \\
\hline & Tikus B2 & 74 & 186 & 600 & 600 & 361 & 56 & 436 \\
\hline & Tikus B3 & 116 & 146 & 499 & 369 & 212 & 84 & 309 \\
\hline & Rata-rata & 90,3 & 174 & 525 & 473 & 314,7 & 75,7 & 448,3 \\
\hline \multirow{4}{*}{ K3 } & Tikus C1 & 106 & 181 & 230 & 287 & 321 & 600 & 600 \\
\hline & Tikus C2 & 75 & 544 & 550 & 554 & 581 & 600 & 600 \\
\hline & Tikus C3 & 77 & 167 & 283 & 300 & 428 & 591 & 600 \\
\hline & Rata-rata & 86 & 297,3 & 354 & 380,3 & 443,3 & 597 & 600 \\
\hline \multirow{4}{*}{ K4 } & Tikus D1 & 63 & 167 & 255 & 600 & 600 & 542 & 461 \\
\hline & Tikus D2 & 79 & 111 & 140 & 111 & 108 & 92 & 105 \\
\hline & Tikus D3 & 60 & 432 & 489 & 543 & 487 & 115 & 303 \\
\hline & Rata-rata & 67,3 & 236,7 & 294 & 418 & 398,3 & 249,7 & 289,7 \\
\hline \multirow{4}{*}{ K5 } & Tikus E1 & 113 & 200 & 255 & 143 & 125 & 117 & 104 \\
\hline & Tikus E2 & 80 & 313 & 350 & 375 & 459 & 384 & 359 \\
\hline & Tikus E3 & 71 & 206 & 397 & 517 & 600 & 575 & 518 \\
\hline & Rata-rata & 88 & 239,7 & 334 & 345 & 394,7 & 358,7 & 327 \\
\hline \multirow{4}{*}{ K6 } & Tikus F1 & 66 & 270 & 510 & 600 & 600 & 530 & 497 \\
\hline & Tikus F2 & 71 & 500 & 548 & 600 & 600 & 517 & 405 \\
\hline & Tikus F3 & 74 & 492 & 538 & 600 & 600 & 345 & 254 \\
\hline & Rata-rata & 70,3 & 420,7 & 532 & 600 & 600 & 464 & 385,3 \\
\hline
\end{tabular}

Berdasarkan hasil perhitungan kadar glukosa darah rata-rata pada ketiga kelompok perlakuan, penurunan kadar glukosa darah pada ketiga kelompok tidak signifikan mungkin karena pengukuran dilakukan hanya sampai jam ke-24 sehingga efek penurunan kadar glukosa darah oleh ekstrak umbi bawang putih 
yang diberikan belum terlalu terlihat. Oleh karena itu, perlu dilakukan penelitian lebih lanjut dengan waktu pengukuran yang lebih lama.

Efek penurunan kadar glukosa darah yang berbeda pada ketiga kelompok perlakuan tersebut juga kemungkinan dipengaruhi oleh jumlah kandungan kimia yang terdapat dalam tiap dosis, sehingga perlu di lakukan penelitian lebih lanjut dengan dosis yang lebih banyak. Kandungan kimia pada ekstrak umbi bawang putih yang berperan dalam menurunkan kadar glukosa darah yaitu allisin dan allin. Allisin dan allin dapat merangsang pankreas untuk mengeluarkan lebih banyak insulin. Allisin juga berperan sebagai antioksidan yang dapat menghambat aktifitas reactive oxygen species (ROS) yang terbentuk karena induksi aloksan. ${ }^{14,15}$ Oleh sebab itu, perlu dilakukan penelitian lebih lanjut untuk mengetahui kandungan kimia apa yang terdapat dalam umbi bawang putih yang berperan untuk menurunkan kadar glukosa darah.

Pada penelitian ini didapatkan kadar glukosa darah yang beragam pada ketiga hewan uji pada setiap kelompok walaupun diberi perlakuan yang sama. Hal ini dikarenakan jumlah hewan uji pada tiap kelompok hanya sedikit sehingga didapatkan hasil pengukuran yang kurang seragam pada tiap kelompok. Oleh karena itu, perlu penelitian lebih lanjut dengan menggunakan hewan uji yang lebih banyak.

\section{SIMPULAN DAN SARAN}

Berdasarkan hasil penelitian maka dapat disimpulkan bahwa ekstrak umbi bawang putih dengan dosis $6 \mathrm{mg} / 200 \mathrm{gBB}$ tikus dan $12 \mathrm{mg} / 200 \mathrm{gBB}$ tikus mempunyai efek menurunkan kadar glukosa darah tikus Wistar. Perlu dilakukan penelitian lebih lanjut dengan menggunakan hewan uji yang lebih banyak, dosis ekstrak umbi bawang putih yang besar, dan waktu pengukuran yang lebih lama. Perlu penelitian lanjutan pula untuk mengetahui kandungan kimia dalam umbi bawang putih yang mempunyai efek menurunkan kadar glukosa darah.

\section{DAFTAR PUSTAKA}

1. World Health Organization. About Diabetes. [diakses 2014 Sep 19]. Tersedia dari: http://www.who.int/diabetes/action onli ne/basics/en/.

2. International Diabetes Federation. Diabetes Atlas. Edisi ke-6. [diakses 2014 Okt 15]. Tersedia dari: http://www.idf.org/sites/default/files/EN _6E_Atlas_Full_O.pdf.

3. Badan Penelitian dan Pengembangan Kesehatan Kementrian Kesehatan Republik Indonesia. Riset Kesehatan Dasar 2013. h. 87-9.

4. Modak, M, Dixit P, Londhe J, Gaskadbi S, Devasagayam TPA. Indian herbs and herbal drugs used for the treatment of diabetes. Journal of Clinical Biochemistry and Nutrition. 2007;40(3):163-73. [diakses 2014 Sep 20]. Tersedia dari: http://www.ncbi.nlm.nih.gov/pmc/article s/PMC2275761/

5. Mistra. Tiga jurus melawan diabetes melitus. Jakarta: Puspaswara; 2008. h. 39.

6. Greenwood-Robinson M. Control Diabetes in 6 Easy Steps. New York: St. Martin's Griffin; 2002. 143.

7. Nugroho AE. Review: Hewan percobaan diabetes melitus: Patologi dan mekanisme aksi diabetogenik. Biodiversitas 2006;7(4);378-82. [diakses 2014 Sep 22]. Tersedia dari: http://www.biodiversitas.mipa.uns.ac.id/ D/D0704/D070415.pdf.

8. Novomix ${ }^{\circledR} 30$ Dosing Guidelines. [diakses 2014 Okt 15]. Tersedia dari:http://www.novonordisk.com/image s/diabetes/pdf/novomix_dosing_guidelin es_v18.pdf.

9. Reagen-Shaw S, Nihal M, Ahman N. Dose translation from animal to human studies revisited. The FASEB Journal. 2007;22;819-23.

10. Tattelman, E. Health effect of garlic. Am Fam Physician 2005;72(1);103-6. [diakses 2014 Sep 22]. Tersedia dari: 
http://www.aafp.org/afp/2005/0701/p10 3.html.

11. Harmita, Radji M. Buku Ajar Analisis Hayati. Edisi 3. Jakarta: EGC; 2008. h. 66.

12. Gad SC. The Rat. Dalam: Gad SC. Animal Models in Toxicology. Edisi 2. New York: Taylor \& Francis; 2007. h. 152-96.

13. Product information insulin aspart. [diakses 2015 jan 5]. Tersedia dari: http://www.novonordisk.com.au/media/ PIs/Novorapid NovoMix PI3a.pdf.
14. Hernawan UE, Setyawan AD. Review: Senyawa organosulfur bawang putih (Allium Sativum L.) dan aktifitas biologinya. Biofarmasi 2003;1(2);65-75.

15. Ankur R, Sahjad A. Alloxan induced diabetes: mechanisms and effects. International Journal of Research in Pharmaceutical and Biomedical Sciences 2013;(3);819-23. [diakses 2014 Sep 22]. Tersedia dari: http://www.ijrpbsonline.com/files/593290.pdf. 